\title{
Factors affecting the voluntary intake of food by sheep
}

\section{The role of distension, flow-rate of digesta and propulsive motility in the intestines}

\author{
BY W. L. GROVUM \\ Department of Biomedial Sciences, Ontario Veterinary College, University of Guelph, \\ Guelph, Ontario $N_{1} G 2 W_{2}$, Canada \\ AND G. D. PHILLIPS \\ Department of Animal Science, University of Manitoba, Winnipeg, Manitoba $\mathrm{R}_{3} \mathrm{~T}_{2} \mathrm{N2}$, \\ Canada
}

\author{
(Received 28 September 1977 - Accepted I9 December 1977)
}

\begin{abstract}
I. Twelve sheep fitted with abomasal cannulas were given ad lib. access to a diet of chopped lucerne (Medicago sativa) hay to ascertain if the amount of digesta being transported by the intestines was limiting intake. If this was the situation, pumping a solution of the bulk-laxative methylcellulose (100 $\mathrm{g} / \mathrm{kg} ; \mathrm{MC})$ into the abomasum should have reduced intake in proportion to the mass of digesta attributable to the MC and associated water. In preliminary experiments faecal water and wet matter ouptuts increased by $6 \cdot 2$ and $7.4 \mathrm{~g} / \mathrm{g} \mathrm{MC}$ powder respectively.

2. The infusion of $2.95 \mathrm{~kg} \mathrm{MC} / \mathrm{d}$ did not affect food intake even though wet faecal output increased from a control value of 2.436 to $4.616 \mathrm{~kg} / \mathrm{d}$. The transit time of ${ }^{51} \mathrm{Cr}-\mathrm{EDTA}$ through the intestines decreased only slightly during the infusion indicating that $\mathrm{MC}$ produced a marked increase in the mass of intestinal contents. Increasing the rate of infusion to $5: 336 \mathrm{~kg} / \mathrm{d}$ increased wet faecal output to $5.437 \mathrm{~kg} / \mathrm{d}$, did not change transit time but significantly decreased food intake presumably to protect the intestines from overdistension. After stopping the infusion, food intakes and faecal outputs returned to control values but transit time remained unchanged. The intake of chopped lucerne hay by sheep was not limited by the capacity of the small and large intestines to transport bulk as intake was maintained even though wet faecal output was doubled and the intestines apparently became markedly distended.
\end{abstract}

The voluntary intakes of roughage diets by ruminants are thought by many workers to be limited by distension of the reticulo-rumen (Crampton, Donefer \& Lloyd, I960; Blaxter, Wainman \& Wilson, I96I ; Balch \& Campling, 1962; Montgomery \& Baumgardt, I965; Ulyatt, Blaxter \& McDonald, 1967) or physical factors involving the entire gut (Conrad, Pratt \& Hibbs, I964). To the contrary though, Carr \& Jacobson (1967) found that intake of chopped lucerne (Medicago sativa) by cattle was unaffected by adding up to approximately $9 \mathrm{~kg}$ water to rubber bags in the rumen. Intakes of roughages were found in other studies to increase with increasing digestibility (Crampton, 1957; Blaxter et al. I96r ; Blaxter \& Wilson, 1962; Conrad et al. 1964). The weight of dry faeces excreted daily by either the sheep or the cattle in these experiments were similar for diets differing markedly in digestibility. This observation is similar to that of Lehmann (1941) as cited by Conrad, Pratt \& Hibbs (1964). Thus there appeared to be an upper limit to the amount of indigestible fibre that could be either degraded in or passed through the digestive tract. The argument that the intake of roughage by sheep and cattle was limited by distension of the reticulo-rumen was not completely defensible since the capacity of the intestines to transport digesta had not been investigated. Information on this subject is now reported along with evidence indicating that intestinal distension and propulsive activity were not likely limiting intakes of lucerne chaff by sheep. 


\section{EXPERIMENTAL \\ Sheep and surgery}

Cross-bred Suffolk wethers, 6 months to I year of age were used in Expt I (nos 2-5), Expt 2 (nos I-12) and Expt 3 (nos I, 5, 6 and I 2). The mean ( \pm SE) body-weight of the twelve sheep was $3 I^{1} \cdot 6 \pm 0.8 \mathrm{~kg}$ before surgery and Expt $\mathrm{I}$ and $49.4 \pm \mathrm{I} \cdot 2 \mathrm{~kg}$ at the end of Expt 2 . The animals were treated for internal and external parasites before surgery commenced. Each sheep was fitted in the abomasum with a T-shaped cannula made out of polyvinyl chloride. The sheep were allowed to recover from surgery for $7-\mathrm{I} 4 \mathrm{~d}$ before the experiments commenced.

\section{Housing, feeding and diets}

The sheep were kept in an area which was always illuminated. Their daily rations were given continuously over $24 \mathrm{~h}$ with the use of an automatic belt-type feeder (Phillips, unpublished). Water was always available. Retinol, cholecalciferol and $\alpha$-tocopherol were added to the drinking-water at intervals of I month.

The composition $(\mathrm{g} / \mathrm{kg}$ ) of the lucerne-chaff diets used in Expt $\mathrm{I}$ and in Expts 2 and 3 were 29 and 30 nitrogen, 9 and $I_{5}$ fat, 33 I and 310 crude fibre, 88 and $10 \mathrm{r}$ ash and 543 and 544 crude carbohydrate (nitrogen-free extract; NFE) respectively.

In Expts 2 and 3 the sheep were fed $a d$ lib. so as to maintain the amount of 'weighbacks' at the end of each day between 100 and $300 \mathrm{~g}$. Each sheep was also given approximately $15 \mathrm{~g} / \mathrm{d}$ mineral mix consisting of sodium chloride treated with trace minerals, calcium phosphate and calcium carbonate in equal amounts by weight.

\section{Collection and drying of faeces}

Faeces were collected in plastic bags that were cut along their closed ends, glued to the sheep with cement (3M Bull No. EC 1578 ; Minnesota Mining and Manufacturing of Canada Ltd, London, Canada) and held closed at the outlet with wide elastic bands. Duplicate samples of wet faeces collected daily from each sheep were dried to constant weight at $73^{\circ}$ in a forced-air oven.

\section{Transit time of digesta in the intestines}

${ }^{51} \mathrm{Cr}$-EDTA was injected into the abomasum of each sheep via the cannula between 08.00 and 10.00 hours. The voided faeces were collected at intervals of $30 \mathrm{~min}$ starting $3 \mathrm{~h}$ after the injections. The time period for first appearance of ${ }^{51} \mathrm{Cr}$-EDTA in faeces of each sheep was determined by scanning the samples with a portable, well-type scintillation counter.

\section{Extraction of fluid from faeces}

Fluid could not be removed from wet sheep faeces using a hydraulic press so a volumetric pressure plate extractor (Soil Moisture Equipment Co., Santa Barbara, California), used normally to extract water from soils, was used. A pressure of $\mathrm{N}_{2}$ gas of $\mathrm{I} \cdot 38 \times 10^{5} \mathrm{~N} / \mathrm{m}^{2}$ was maintained in the chamber and fluid was collected below the pressure plate into a container sealed to the atmosphere.

\section{Increasing flow of contents in the intestines}

The hydrophilic colloid methylcellulose (Methocel, MC 10, premium grade; Dow Chemical Co., Midland, Michigan; MC) was infused into the abomasum as a solution ( $100 \mathrm{~g} / \mathrm{kg})$ to increase the flow of digesta through the intestines. This product has been declared safe and cleared for uses in food consumed by humans. Each of the seventy anhydroglucose units constituting one molecule of MC had on average 1.64-1.92 methoxyl groups 
substituted for hydrogen atoms of hydroxyls (maximum of three substitutions). The product should not therefore be absorbed from the gut or be digested to a great extent by microorganisms (Reese, Siu \& Levinson, 1950). Tainter \& Buchanan (I954) reviewed information on the water-retaining abilities of a range of colloid laxatives and reported that $\mathrm{MC}$ increased wet faecal output in man by $4-10 \mathrm{~g} / \mathrm{g}$ dry powder administered orally.

\section{Electrolytes and osmolality in faecal fuid}

The concentrations of sodium ions and potassium ions were determined with a Technicon AutoAnalyzer (Model II, Technicon Instruments Corp., Tarrytown, New York, USA) and those of calcium ions and magnesium ions with an atomic absorption spectrophotometer. Osmolalities were determined on $0.25 \mathrm{ml}$ samples of the fluid by measuring freezing-point depressions.

\section{$\operatorname{Expt} \mathrm{I}$}

The purpose was to determine if long-term infusions of MC into the abomasum of sheep would produce nutrient deficiencies or electrolyte imbalances in the animals. Each of four sheep were given $400 \mathrm{~g}$ lucerne chaff/d for a preliminary control period (period no. 1 ) of $13 \mathrm{~d}$, an infusion period (period no. 2) of $17 \mathrm{~d}$ and a final control period (period no. 3 ) of $\mathrm{I} 6 \mathrm{~d}$. During period no. 2 , the equivalent of $93 \mathrm{~g}$ dry $\mathrm{MC} / \mathrm{d}$ was pumped into the abomasum of each sheep. The amount of food offered after period no. 3 was increased to $850 \mathrm{~g} / \mathrm{d}$ for $24 \mathrm{~d}$ (period no. 4) to determine the effect of increasing faecal output on the water content of faeces.

The daily collections of wet faeces from each sheep were weighed and samples were obtained in duplicate and dried. The dry matter (DM) from periods nos. 2 and 3 were analysed for contents of $\mathrm{N}$, fat, fibre, NFE, ash, $\mathrm{Na}^{+}$and $\mathrm{K}^{+}$. The outputs of $\mathrm{Ca}^{2+}$ and $\mathrm{Mg}^{2+}$ in faecal fluid were also determined.

\section{Expt 2}

The purpose was to ascertain if the passage of digesta through the intestines was limiting the intakes of roughage diets by sheep. Twelve sheep were randomly assigned to receive either infusions of MC (sheep nos 2, 4, 6, 7, 9, I1) or similar volumes of distilled water (sheep nos $1,3,5,8,10,12$ ).

In period no. I, all sheep were given lucerne chaff to appetite for $30 \mathrm{~d}$ to establish their maximal intakes of the roughage. Samples of the food, orts and faeces for each sheep were taken on a daily basis to calculate dry food intake, dry faecal output and the amount of DM in faeces. Apparent digestibilities were determined from these values for days I 9-30 inclusive. In period no. 2, lasting from the end of day 30 to the end of day 44 , the same procedure was followed except that $2.950 \mathrm{~kg} \mathrm{MC}$ solution $(100 \mathrm{~g} / \mathrm{kg}$ ) $/ \mathrm{d}$ and $2.960 \mathrm{~kg}$ distilled water $/ \mathrm{d}$ were infused into the abomasum of the treatment and control sheep respectively. In period no. 3 , from the end of day 44 to the end of day $5 \mathrm{I}$, the daily rates of infusion were increased to an average of $5.336 \mathrm{~kg} / \mathrm{d}$ for the treatment group and $6.770 \mathrm{~kg} / \mathrm{d}$ for the control group. Period no. 4 like period no. I was a control period in which the normal values for food consumption and faecal output were obtained.

The transit time of ${ }^{51} \mathrm{Cr}$-EDTA through the intestines was determined on the last day of each period between 09.00 and 21.00 hours.

Statistical analysis of results. Sheep no. 7 died in period no. 3 and the results from it are reported separately. Thus the treatment group was reduced in size to five sheep in all periods. These individual animal results were analysed in a two-way analysis of variance with a total of $19 \mathrm{df}, 3 \mathrm{df}$ for periods, $4 \mathrm{df}$ for sheep, and $12 \mathrm{df}$ for error. The corresponding values for df for the control group were 23, 3, 5 and 15 respectively. Linear combinations with I and 
I $2 \mathrm{df}$ were used for example to compare transit times for the treatment group in periods nos $I$ and 4 with those in periods nos 2 and 3. The observations for weight of dry food consumed/d and for total weights of wet or dry faecal material excreted/d were means of values recorded in the last $5 \mathrm{~d}$ of each period.

All differences between period means within the treatment and control groups were tested using the sequential variant of the $Q$ method (Snedecor \& Cochran, 1967). The differences within periods between mean values for the treatment and control groups were analyzed with the Student's $t$ test (two-tailed). Also for example, the changes in individual sheep values from period no. I to period no. 2 in the treatment group $\left(T_{1}-T_{2}\right)$ were compared with similar changes for individuals in the control group $\left(C_{1}-C_{2}\right)$ using Student's $t$ test with 9 df $(n \mathrm{I}+n 2-2)$.

\section{Expt 3}

$a$. The purpose of this experiment was to ascertain if the relatively low intake of sheep no. I $\left(84 \mathrm{~g} \mathrm{DM} / \mathrm{kg}\right.$ body-weight ${ }^{0.75} v$. I00 $\mathrm{g} \mathrm{DM} / \mathrm{kg}$ body-weight ${ }^{0.75}$ on the average for the other sheep) was due to a limited ability of its intestines to transport digesta. Sheep nos. I and I 2 were given food to appetite throughout this experiment. In periods nos. I and 3, I 4 and I I $\mathrm{d}$ in duration respectively, normal values for intakes were obtained. In period no. 2 spanning I5 d, sheep no. I had $3.342 \mathrm{~kg} \mathrm{MC}$ solution ( $100 \mathrm{~g} / \mathrm{kg}$ ) $/ \mathrm{d}$ pumped into its abomasum and the control animal was given a similar weight of distilled water.

$b . \mathrm{MC}$ in solution was infused into the abomasum of one sheep at a high rate over a short period of time to gain preliminary information on the amount of distension that was required to suppress food intake. The experiment was conducted as described for Expt $3 \mathrm{a}$ except that sheep no. 6 was infused with $7.942 \mathrm{~kg} \mathrm{MC}$ solution/d for $36 \mathrm{~h}$ and sheep no. 5 was infused with distilled water at the rate of $10 \mathrm{~kg} / \mathrm{d}$.

\section{RESULTS}

\section{Expt $\mathrm{r}$. Effectiveness of $M C$ in increasing faecal output}

The DM content of faeces decreased from control values near $450 \mathrm{~g} / \mathrm{kg}$ to approximately $250 \mathrm{~g} / \mathrm{kg}$ within $2 \mathrm{~d}$ of starting the infusion of MC into the abomasum (Fig. 1), but maximal rates of excretion of faecal wet weight were only attained after the fifth day of the infusion. The increases in the amounts of water and wet faeces excreted/d averaged $6 \cdot 19$ and $7: 44 \mathrm{~g} / \mathrm{g}$ dry MC infused respectively. The water content of the faeces was not affected by altering food intake to increase the throughput of digesta comparable to that produced when $\mathrm{MC}$ was infused. The differences in mean faecal DM output/d before and during infusions (days I 8-29) indicated an apparent recovery of MC of $126 \%$. The digestibility of food DM in period no. 1 was 0.617 .

Some chemical characteristics of the faeces are presented in Table I. The MC infused during period no. 2 was apparently recovered in faeces as fibre and as NFE. Subsequent to analyses of variance, linear combinations with I df were used to compare the outputs of $\mathrm{N}$, fat and ash during period no. 2 with the respective average outputs in periods nos. I and 3 . The amount of $\mathrm{N}$ excreted/d was not affected by the infusion of MC but the amount of fat excreted was decreased $(P<0.0 \mathrm{I})$ and the amount of ash was increased $(P<0.0 \mathrm{I})$. The faecal fluid was hypotonic in periods nos. 2 and 3 . The weights of $\mathrm{Na}^{+}, \mathrm{K}^{+}, \mathrm{Ca}^{2+}$ and $\mathrm{Mg}^{2+}$ excreted in faecal water, calculated from their concentrations in faecal water and the weight of water excreted $/ \mathrm{d}$ (Table 1 ), were respectively $0.32, \mathrm{I} \cdot 79,0.06$ and $0.35 \mathrm{~g} / \mathrm{d}$ in period no. 2 and $0.05,0.35,0.07$ and $0.24 \mathrm{~g} / \mathrm{d}$ in period no. 3. The differences between periods nos. 2 and 3 were significant only for $\mathrm{K}^{+}(P<0.05)$ by Student's $t$ test on pair differences. 


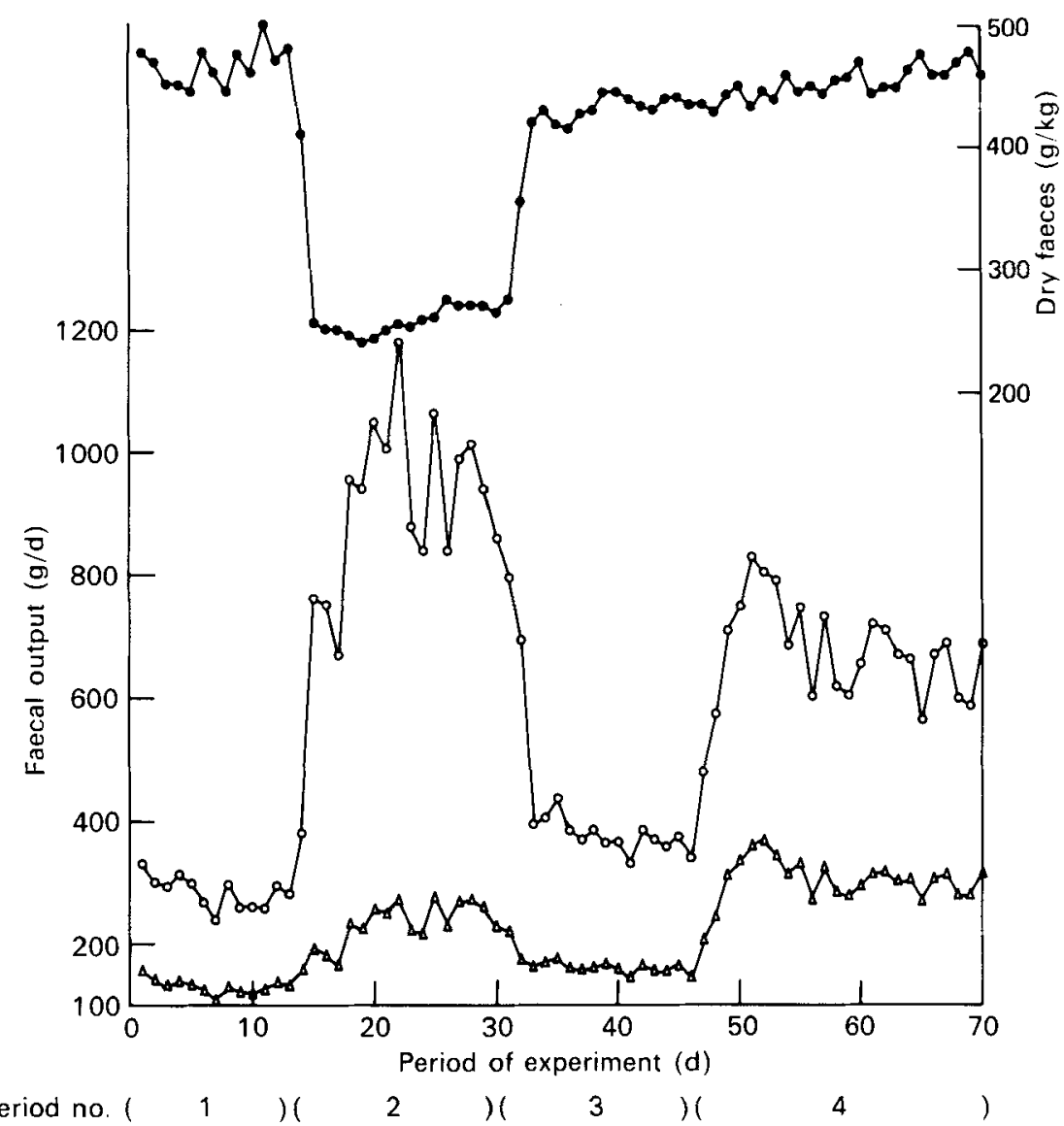

Fig. 1. Expt I. The effect of infusions of methylcellulose (MC) into the abomasum of sheep on the dry matter content of faeces $(\mathrm{g} / \mathrm{kg})$ and on the weights of wet $(\mathrm{g})(\mathrm{O}-\mathrm{O})$ and dry $(\Delta-\Delta)$ faeces excreted daily. Four sheep were given $400 \mathrm{~g}$ lucerne chaff $/ \mathrm{d}$ in periods nos $\mathrm{I}-3$ and $850 \mathrm{~g} / \mathrm{d}$ in period no. 4. MC solution ( $100 \mathrm{~g} / \mathrm{kg}$ ) was infused during period no. 2 at the rate of $930 \mathrm{~g} / \mathrm{d}$ into each sheep. For details of experimental procedures, see p. 324.

\section{Expt. 2. Effect of MC on food intake}

Comparisons between treatment and control groups. The mean weights of dry lucerne chaff consumed/d and of wet and dry faeces excreted/d are given for the entire experiment in Fig. 2. Means of these values for the last $5 \mathrm{~d}$ in each period are given in Table 2 along with the mean transit times of ${ }^{51} \mathrm{Cr}$-EDTA in the intestines. The treatment and control sheep were not significantly different with regard to either the weights of dry lucerne chaff consumed or of wet and dry faeces excreted/d in periods nos I and 4. Digestibilities of food DM were also similar being $0.586 \pm 0.006$ (SE) and $0.595 \pm 0.004$ respectively. However, in periods nos. 2 and 3 the weights of wet and dry faeces/d were significantly greater in the treatment group than in the control group $(P<0.0 \mathrm{I})$. Only in period no. 3 was the food intake of the treatment sheep significantly smaller than that of the control sheep $(P<0.05)$. The differences in transit time between the two groups were not significant in any of the four periods.

Comparisons within the control group. In the control group, the weights of dry food consumed/d and of dry faeces excreted tended to increase throughout the experiment. The 


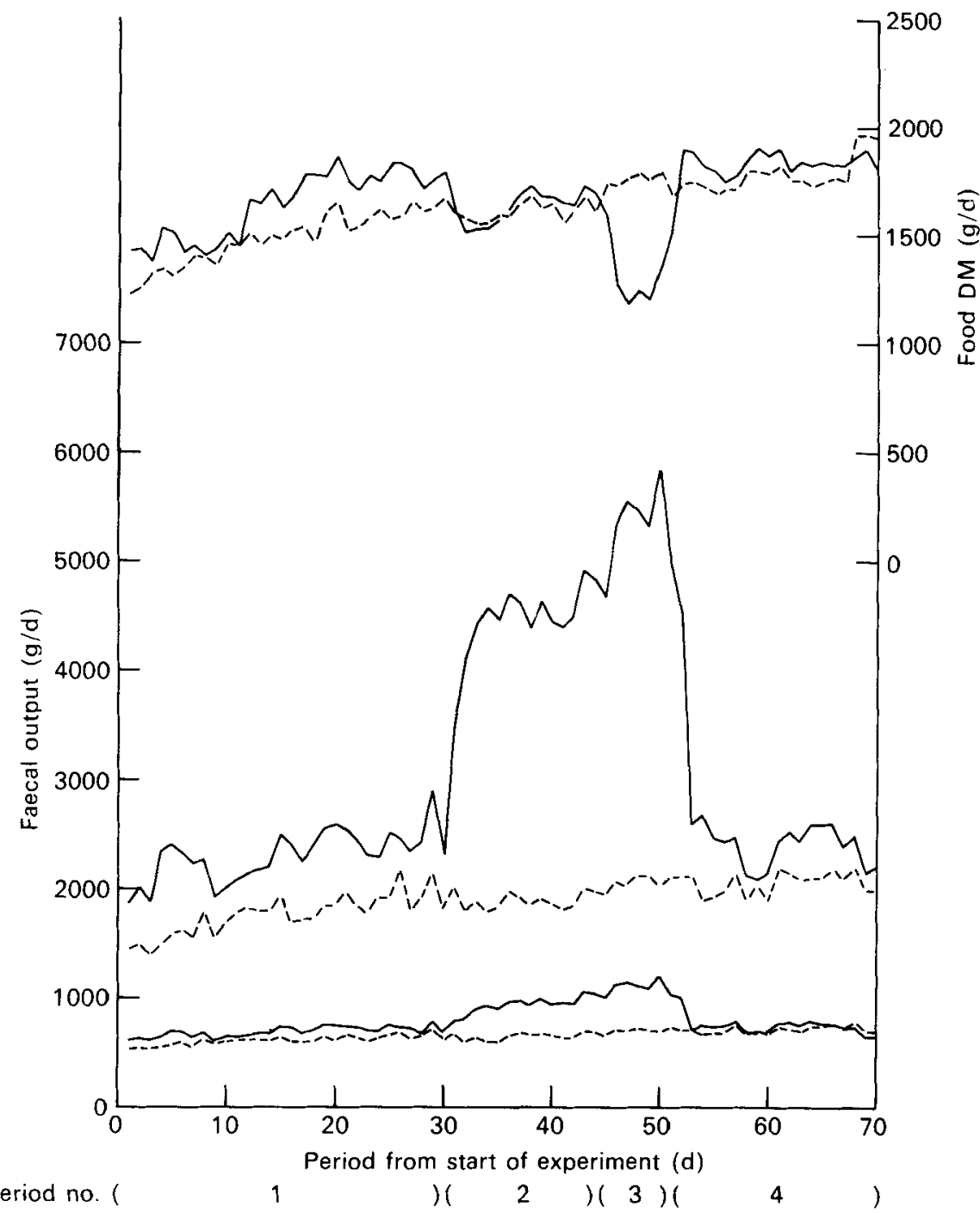

Fig. 2. Expt 2. The effect of infusions of methylcellulose (MC) solution and distilled water into the abomasum on the voluntary consumption of lucerne chaff dry matter (DM) $(g / d)$ and on the weights of wet (middle set of lines) and dry (bottom set of lines) faeces excreted $(\mathrm{g} / \mathrm{d})$ in five treatment (-) and six control (-- ) sheep respectively. Control values were established in periods nos. $\mathrm{I}$ and 4 . The mean rates of infusion of $\mathrm{MC}$ solution $(\mathrm{I} 00 \mathrm{~g} / \mathrm{kg})$ and water were respectively $2 \cdot 950$ and $2.960 \mathrm{~kg} / \mathrm{d}$ in period no. 2 and 5.336 and $6.770 \mathrm{~kg} / \mathrm{d}$ in period no. 3. For details of experimental procedures, see p. $\mathbf{3 2 5}$.

means for food intake and dry faecal output in periods nos. I and 2 were significantly less than the corresponding means in period no. 4 (Table 2). There were no significant differences among the period means for the weight of wet faeces excreted/d or for the transit time of ${ }^{51} \mathrm{Cr}$-EDTA in the intestines.

Comparisons within the treatment group. The sheep in the treatment group consumed significantly less food during period no. 3 than during periods nos. I, 2 and 4 in which intakes were similar (Table 2). The weights of wet and dry faeces excreted/d were significantly greater in periods nos. 2 and 3 than in periods nos. 1 and 4 and the values in period no. 3 
Table 2. Expt 2 Effects of methylcellulose $(M C)$ infusions into the abomasum of sheep given lucerne chaff ad lib. on dry food intake, faecal output and intestinal transit time.

(In periods nos. I and 4 control values were obtained in all animals whereas in periods nos. 2 and 3 , five treatment sheep received 295 and $544 \mathrm{~g} / \mathrm{d}$ dry $\mathrm{MC}$ and six control sheep received 2960 and $6770 \mathrm{~g}$ distilled water respectively)

\begin{tabular}{|c|c|c|c|c|c|c|}
\hline \multirow[b]{2}{*}{ Group no. } & \multicolumn{4}{|c|}{ Period no.* } & \multirow{2}{*}{\multicolumn{2}{|c|}{$\begin{array}{cc}\text { Statistical } & \begin{array}{c}\text { Standard } \\
\text { error of } \\
\text { treatment }\end{array} \\
\text { significance } F & \text { means }\end{array}$}} \\
\hline & $\mathbf{I}$ & 2 & 3 & 4 & & \\
\hline \multicolumn{7}{|c|}{ Dry food intake $(\mathrm{g} / \mathrm{d})$} \\
\hline $\begin{array}{l}\text { Treatment } \\
\text { Control }\end{array}$ & $\begin{array}{l}1815^{2} \\
1626^{a}\end{array}$ & $\begin{array}{l}1678^{a} \\
1624^{a}\end{array}$ & $\begin{array}{l}1301^{\mathrm{b}} \\
1755^{\mathrm{ab}}\end{array}$ & $\begin{array}{l}I 843^{\mathrm{a}} \\
1821^{\mathrm{b}}\end{array}$ & $\begin{array}{l}P<0.001 \\
P<0.01\end{array}$ & $\begin{array}{r}91 \\
135\end{array}$ \\
\hline \multicolumn{7}{|c|}{ Wet faecal output $(\mathrm{g} / \mathrm{d})$} \\
\hline $\begin{array}{l}\text { Treatment } \\
\text { Control }\end{array}$ & $\begin{array}{l}2436^{8} \\
1920\end{array}$ & $\begin{array}{l}4616^{b} \\
1899\end{array}$ & $\begin{array}{l}5437^{\mathrm{c}} \\
2088\end{array}$ & $\begin{array}{l}2369^{\mathrm{a}} \\
2087\end{array}$ & $\begin{array}{c}P<0.001 \\
\text { NS }\end{array}$ & $\begin{array}{l}231 \\
209\end{array}$ \\
\hline \multicolumn{7}{|c|}{ Dry faecal output $(\mathrm{g} / \mathrm{d})$} \\
\hline $\begin{array}{l}\text { Treatment } \\
\text { Control }\end{array}$ & $\begin{array}{l}744^{\mathrm{a}} \\
655^{\mathrm{a}}\end{array}$ & $\begin{array}{l}987^{b} \\
665^{a}\end{array}$ & $\begin{array}{l}1118^{\mathrm{c}} \\
716^{\mathrm{ab}}\end{array}$ & $\begin{array}{l}715^{a} \\
736^{b}\end{array}$ & $\begin{array}{l}P<0.001 \\
P<0.05\end{array}$ & $\begin{array}{l}39 \\
57\end{array}$ \\
\hline \multicolumn{7}{|c|}{ Intestinal transit time $\dagger$ (min) } \\
\hline $\begin{array}{l}\text { Treatment } \\
\text { Control }\end{array}$ & $\begin{array}{l}437^{\mathrm{a}} \\
389\end{array}$ & $\begin{array}{l}371^{b} \\
370\end{array}$ & $\begin{array}{l}377^{b} \\
415\end{array}$ & $\begin{array}{l}369^{b} \\
401\end{array}$ & $\begin{array}{c}P<0.05 \\
\text { NS }\end{array}$ & $\begin{array}{l}22 \\
22\end{array}$ \\
\hline
\end{tabular}

8. b. c . Mean values in a horizontal row having different superscripts were significantly different $(P<0.05)$ by the Q method (Snedecor \& Cochran, 1967).

NS, not significant.

* For details, see p. 325.

+ Time for ${ }^{51} \mathrm{Cr}$-EDTA injected in the abomasum first to appear in faeces.

were significantly greater than those in period no. 2 (Table 2). The transit time of ${ }^{51} \mathrm{Cr}$-EDTA in the intestines was significantly greater in period no. I than in periods nos. 2,3 or 4 . However, the average of the transit times in control periods ncs. I and 4 was not significantly different from that for the infusion periods nos. 2 and 3.

Comparisons within control and treatment groups. The increase in the mean weight of food consumed/d by the control group between periods nos. I and 4 ( $195 \mathrm{~g}$ ) was not significantly greater than that for the treatment group ( $28 \mathrm{~g})$, indicating that the treatment animals were not adversely affected by the infusion of MC. The decrease in dry food intake by the treatment group between the last $5 \mathrm{~d}$ of both periods nos. I and $2(\mathrm{I} 37 \mathrm{~g} / \mathrm{d})$ was not significantly different from that for the control group $(2 \mathrm{~g} / \mathrm{d})$. However, the decrease between the last $5 \mathrm{~d}$ of period no. I and the first $5 \mathrm{~d}$ of period no. 2 was significantly greater in the treatment group $(268 \mathrm{~g} / \mathrm{d})$ than in the control group $(5 \mathrm{Ig} / \mathrm{d} ; P<0.01)$, indicating that the infusion of $\mathrm{MC}$ into the abomasum at the rate of $295 \mathrm{~g} \mathrm{DM} / \mathrm{d}$ had a transient effect on the voluntary consumption of food by the sheep in the treatment group.

Individual animal differences. There were marked differences between individual sheep within the treatment group in their food intakes during the infusion of MC (Fig. 3). During period no. 3 , the voluntary consumption of food by sheep no. 6 was affected only slightly but there was a large reduction in intake in sheep no. 9. There appeared to be a transient decrease in intake of food by sheep nos. 6 and 2 during the first part of period no. 2. The pattern of food intake exhibited by sheep no. 7 during period no. 2 was peculiar. The output of wet faeces by this sheep was much less than expected during the first $4 \mathrm{~d}$ of period no. 2 . A greatly increased faecal output occurred during days 5-8 of this period, and thus preceded 


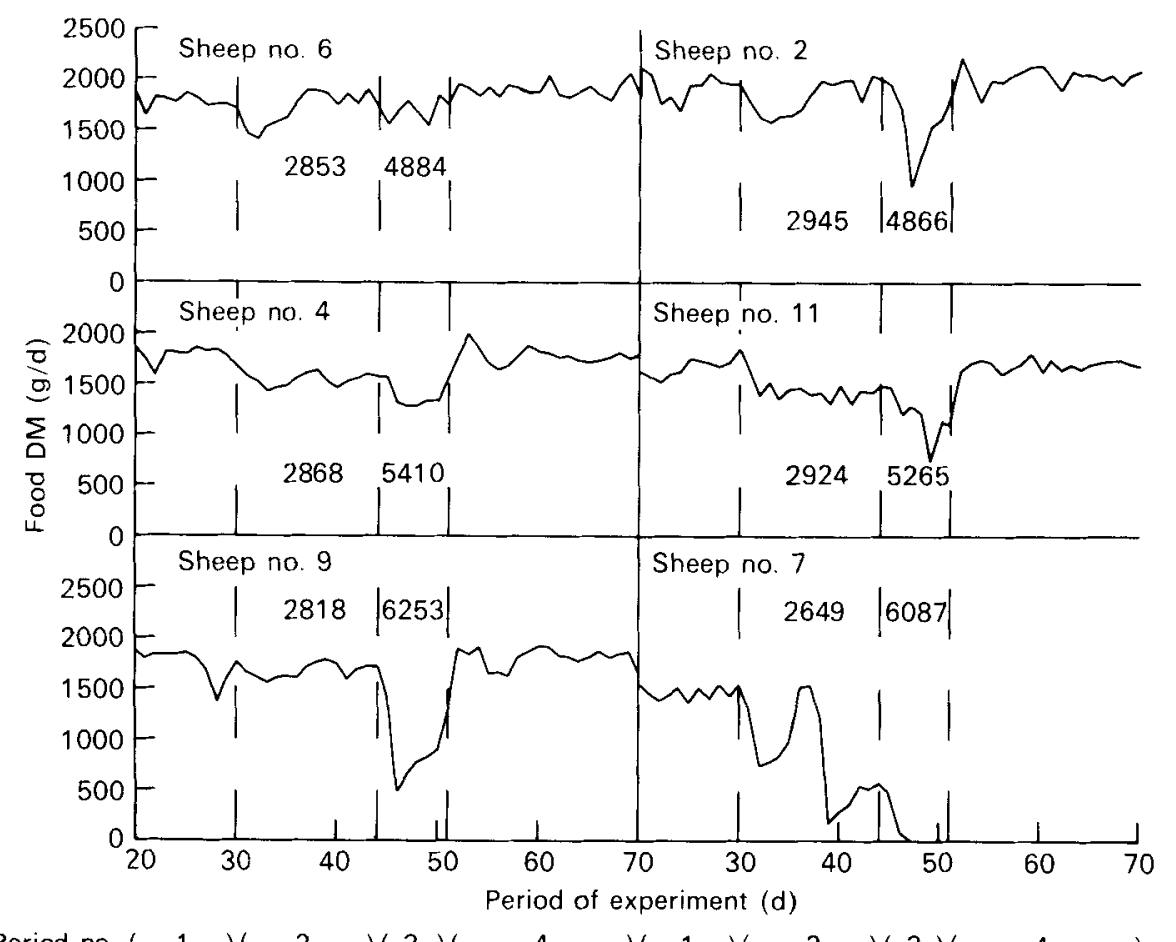

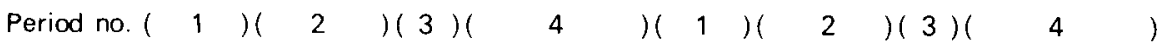

Fig. 3. Expt 2. The effect of infusions of methylcellulose $(\mathrm{MC})$ solution $(100 \mathrm{~g} / \mathrm{kg})$ into the abomasum on the voluntary consumption of lucerne chaff dry matter (DM) ( $g / d$ ) by sheep. Control values were established in periods nos. I and 4 . The values for individual sheep (nos. 2, 4, 6, 7, 9, I I) are mean weights of $\mathrm{MC}$ solution pumped $\mathrm{g} / \mathrm{d}$. For details of experimental procedures, see p. 325 .

the major peak of food intake shown in Fig. 3. The output of wet faeces was again much lower than expected between days 39-48 of the experiment and the animal died on day 49. The weights of contents in the reticulo-rumen, abomasum, small intestine, caecum and proximal colon and spiral colon were $3260,2000,900, \mathrm{I} 800$ and $530 \mathrm{~g}$ respectively.

\section{Expt. 3. Effect of $M C$ on food intake}

a. The intake of lucerne chaff and the output of wet and dry faeces by the control sheep were relatively constant throughout the experiment (Fig. 4 a). How'ever, the intake of food by sheep no. I, infused with MC, decreased by approximately $50 \%$ between days 2 and 5 of period no. 2 and then returned to normal. During the first $4 \mathrm{~d}$ of period no. 2 , the outputs of wet and dry faeces/d by this sheep were less than expected indicating that the animal was accumulating bulk within the abomasum or the intestines. The apparent recovery of infused $\mathrm{MC}$ in faeces was approximately $\mathrm{I} 14 \%$.

$b$. The intake of lucerne and the output of wet and dry faeces by the control sheep were relatively constant throughout the experiment (Fig. 4b). The intake of food by sheep no. 6 was decreased by approximately $50 \%$ during the first day of period no. 2 but its output of wet faeces was less than normal. The animal ate no food during the first half of day 2 . The infusions were stopped and the sheep ate $350 \mathrm{~g}$ food DM during the remainder of that day. The appetite of sheep no. 6 returned to normal by the fourth day after the start of period no. 2. 


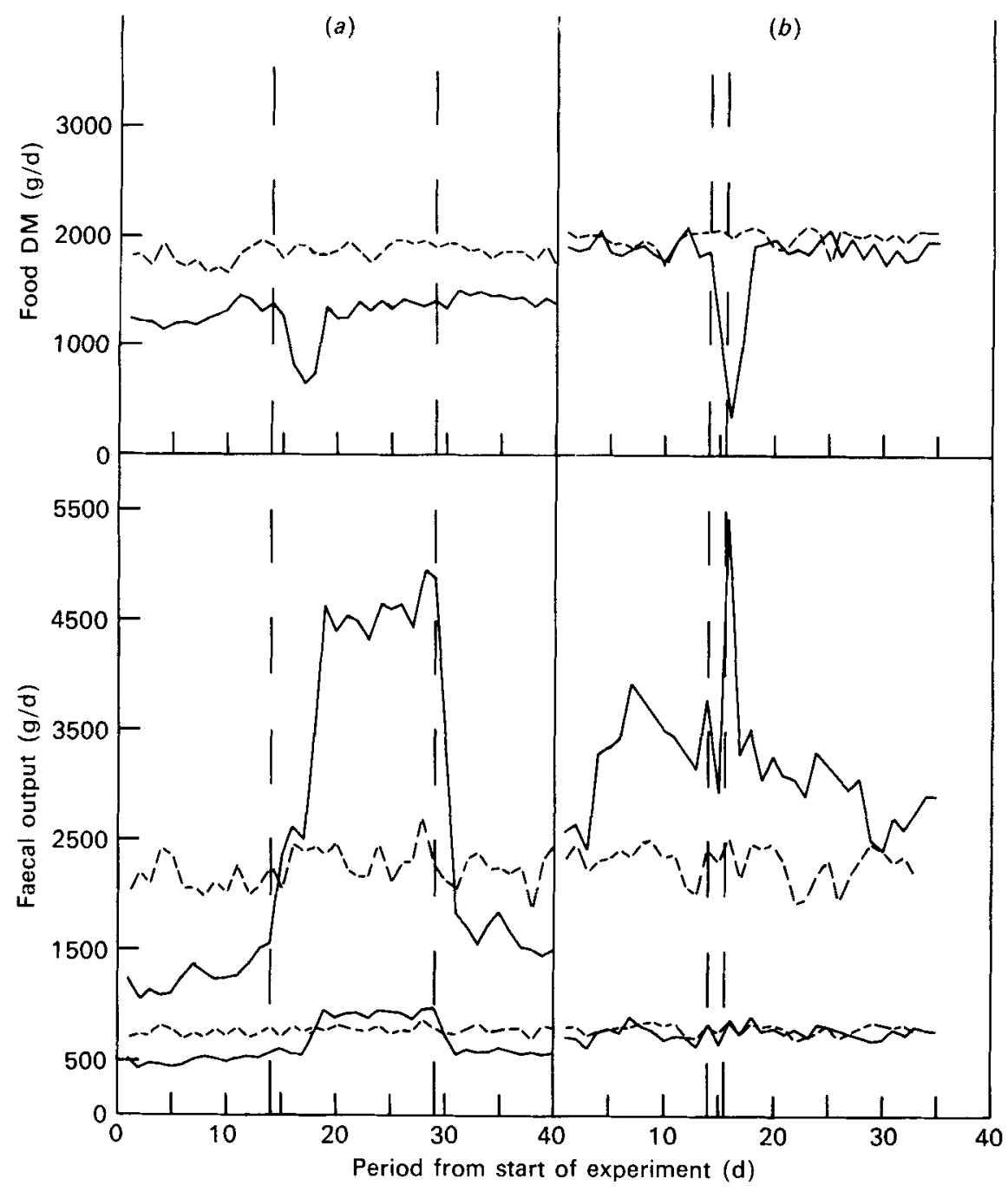

Period no. $\left(\begin{array}{llllll}1 & 1\end{array}\right)(2)(2)\left(\begin{array}{ccc}1 & 3\end{array}\right)$

Fig. 4. Expt 3. The effect of infusing methylcellulose (MC) solution (-) $100 \mathrm{~g} / \mathrm{kg}$ or distilled water (--) into the abomasum on the voluntary consumption of lucerne chaff dry matter (DM) ( $g / d)$ and on the weights of wet (middle sets of lines) and dry (bottom sets of lines) faeces excreted $(\mathrm{g} / \mathrm{d})$. (a), In period no. 2 sheep no. 1 was infused with $3.342 \mathrm{~kg}$ MC solution/d and sheep no. 12 received $3.268 \mathrm{~kg}$ distilled water $/ \mathrm{d}$; (b) sheep no. 6 was infused with $7.942 \mathrm{~kg} \mathrm{MC} / \mathrm{d}$, and sheep no. 5 received $10 \mathrm{~kg}$ distilled water $/ \mathrm{d}$. For details of experimental procedures, see p. 326 .

\section{DISCUSSION}

\section{Effects of $M C$ on faeces}

MC increased wet faecal output in the sheep by $7 \cdot 4 \mathrm{~g} / \mathrm{g}$ dry powder which was within the range of 4-10.5 g/g established for humans (Tainter \& Buchanan, I954). The MC infused was apparently not digested nor absorbed in the intestines of the sheep which agrees with work done on humans (Machle, Heyroth \& Witherup, 1944). The infusion of MC should not have had adverse nutritional effects on the sheep because the outputs of fat and $\mathrm{N}$ in faeces 
were not increased and the outputs of $\mathrm{Na}^{+}$and $\mathrm{K}^{+}$in faecal water were less than the amounts consumed in the food. Less than $10 \%$ of the ash content of the faeces was accounted for by the amounts of $\mathrm{Na}^{+}, \mathrm{K}^{+}, \mathrm{Ca}^{2+}$ and $\mathrm{Mg}^{2+}$ in solution in faecal water.

\section{Effects of $M C$ on food intake and rate of passage}

The voluntary consumption of food by sheep was depressed with extremely high rates of infusions of MC into the abomasum in period no. 3 of Expt 2 and in Expt $3 \mathrm{~b}$. However, intakes were maintained at or near the ad lib. levels in spite of vast increases in faecal output in period no. 2 Expt 2 and in Expt $3 a$. In Expt 2 the output of wet faeces during the latter part of period no. 2 was almost double the quantities excreted during the control periods nos I and 4 but there was little change in the period of time required for ${ }^{51} \mathrm{Cr}$-EDTA to be passed through the intestinal tract and first appear in faeces. This indicated that the velocity of transport or propulsion of digesta through the intestines was maximal at ad lib. intakes and that the intestines apparently accommodated the additional introduced flow of bulk by distending or increasing their lumen diameters. The intestines apparently became even more distended during period no. 3 than during period no. 2 for reasons similar to those already discussed. The reduction in food intake in period no. 3 was presumably due to an upper physiological limit of distension being attained in either the abomasum or the intestines and this may have served to protect the gut from damage. Distension of the abomasum has been shown to depress the intake of pelleted lucerne by sheep (Grovum, unpublished results), so it cannot be argued with confidence that the tension receptors in the intestines were the primary source of afferent activity leading to the reduction in intake. The main point to be made is that the intestines of sheep had a capacity to contain and to transport much more digesta than normal so it was unlikely in this study that distension or propulsive activity were limiting intakes of the lucerne chaff. Hill, Ison, Jones \& Archdeacon ( 1952 ) decreased meal size in dogs by infusing $50 \mathrm{~g}$ of cellulose in suspension into the jejunum but the mechanism of action was not sought. Hoelzel (I947) concluded from swallowing non-nutritive bulk that a sense of fullness can originate from the small intestine as well as from the stomach but that distension of the intestinal tract with bulk only transiently abolished the desire for food. Hertz (I9II) concluded from clinical observations that the sense of fullness accompanying inflation of the stomach or parts of the intestines was due to the development of a critical level of tension in the muscles of the gut wall.

\section{Receptors in the gut and possible relationships to food intake}

Anand \& Pillai (1967) distended the stomachs of cats and monkeys and increased neuronal activity in the ventromedial hypothalamus and decreased it in the lateral hypothalamus. This condition has been associated with satiety by them and others (Oomura, Ooyama, Yamamoto \& Naka, 1967; Debons \& Krimsky, 1972). The afferent loop of this reflex may have involved in series tension receptors in the outer muscle layers of the stomach. They have been identified in the abomasum of sheep (Harding \& Leek, 1972), the stomach of cats (Paintal, 1954; Iggo, 1955, I957a, $b$; Anand \& Pillai, 1967), the duodenum of sheep (Harding \& Leek, 1972), the small intestine of cats (Iggo, 1957a) and the large intestine of the guinea-pig (Crowcroft, Holman \& Szurszewski, I97I) and could have been involved in limiting intake in Expt 2 period no. 3 and in Expt 3b. However, Iggo (1957a) has cautioned that the in series tension receptors in the stomach and small intestine of the cat do not appear to be accurate volume-signalling devices because the firing rate of the receptors were affected by the tone of the smooth muscle. The rate was higher with rapid rates of filling of a segment containing a receptor than with slow and also the rate decreased after muscle relaxation caused the pressure in the segment to decrease. The suppression of intake could 
also have been triggered by receptors which detect the passage of digesta through the gut and the contractions of its musculature (Gernandt \& Zotterman, 1946; Paintal, I957; Iggo, 1957a; Bessou \& Perl, 1966) as the flow of digesta through the sheep was increased markedly above normal values.

\section{Dietary dilution, energy balance and growth}

Sheep and cattle have been shown to compensate up to a point for dilutions of their diets of concentrates by increasing their $a d$ lib, intakes (Baile \& Forbes, 1974). Experiments of this nature are informative about energy balance but they have not provided information on the mechanisms by which the intake of normal and 'adulterated' foods were limited. The growth rates of young chicks were not affected by diluting their diets with 60-300 $\mathrm{g}$ nonnutritive bulk/kg (Peterson, Grau \& Peek, 1954; Rand, Scott \& Kummerow, 1956; Mraz, Boucher \& McCartney, I957; Sibbald, Slinger \& Ashton, I960) indicating that fill in the digestive tract was not normally limiting their intakes of food. When the energy value of a diet given to dogs was diluted with approximately $500 \mathrm{~g}$ cellulose $/ \mathrm{kg}$, the weight of solids consumed was increased but not enough to compensate for the lower energy density and the dogs lost weight (Janowitz \& Grossman, 1949a). Rats have tolerated a dilution of their diets with 200-500 g cellulose $/ \mathrm{kg}$ without adverse effects on energy intake or gain in body-weight (Adolph, 1947; Janowitz \& Grossman, I949a; Strominger, Brobeck \& Cort, I953; Moinuddin \& Lee, 1959). Diluting the normal diets of growing pigs with fibrous materials has not shown consistent effects on growth rate or carcass fatness (Lawrence, 1972). Generally it appears that intakes of food on a day-to-day basis are not limited by the amount of digesta being passed through the digestive tract as animals generally will increase their intakes considerably to compensate for a reduced energy density of food. However, food intake in one meal by dogs was reduced $50 \%$ by adding to their stomachs 20 min before the time of feeding either food or a non-nutritive bulk substance amounting to half of the weight of a normal meal (Janowitz \& Grossman, 1949b). Pettyjohn, Everett \& Mochrie (1963) found that calves consumed only twice as much of a liquid milk substitute having $50 \mathrm{~g} \mathrm{DM} / \mathrm{kg}$ than of another having $150 \mathrm{~g} \mathrm{DM} / \mathrm{kg}$. This attempt to maintain the energy intake by drinking more of the milk substitute was limited, they thought, by fill in the gastrointestinal tract. Overweight women given a preparation of $\mathrm{MC}$ a short time before meals lost significantly more weight over a 6-week period than controls who did not receive the bulk laxative (Yudkin, 1959). It thus appears that distension of the simple stomach or the abomasum of the calf may have some inhibitory influence on food intake in single meals and this may contribute to the inability of animals to compensate for marked amounts of dietary dilution in long-term studies.

\section{General discussion}

The sheep in the experiments now reported may have had their intakes of lucerne chaff limited by distension of the reticulo-rumen since the intestines appeared to have a capacity to move digesta which was far in excess of that required. Whether the sheep would have continued to eat a less palatable diet while $2.95 \mathrm{~kg} \mathrm{MC}$ solution/d passed into their intestines is open to question. Another significant point is that intestinal transit time decreased in past studies as the level of intake was increased (Grovum \& Williams, 1977) but in the experiments now reported with sheep fed ad lib. intestinal transit time could not be reduced even with high rates of infusion of MC into the abomasum. The significance of the sheep attaining a maximal velocity of digesta transport at ad lib. intakes but yet being able to transport more digesta by distending itself is not appreciated as yet. However, it appears that if sheep can be induced to eat more than the normal quantities of roughages, the intestines can 
transport the residues. Welch (1967) found that long polypropylene fibres added to the reticulo-rumen of sheep halved their intakes of hay but that the same material in the ground form had no effect on intake. The long fibres seemingly produced the critical value of distension of the reticulo-rumen even at intakes half of maximal by interfering perhaps with regurgitation, chewing, mixing or the onward passage of particulate matter. The association in sheep of low live-weight gains on pasture with high volumes and weights of digesta in the rumen (Johns, Ulyatt \& Glenday, I963; Rae, Brougham, Glenday \& Butler, 1963) raises the following questions: (a) what was limiting intakes of the sheep that were growing rapidly; (b) is the extent of distension of the reticulo-rumen that will signal satiety a fixed or a variable entity. More research is needed on how and under what conditions distension of the reticulorumen limits intake and growth in ruminants given roughage diets.

The authors are grateful to Mr V. D. Pauls for technical assistance and to the National Research Council of Canada for a grant covering the salary of W.L.G. and the cost of materials.

\section{REFERENCES}

Adolph, E. F. (1947). Am. J. Physiol. 151, I 10.

Anand, B. K. \& Pillai, R. V. (1967). J. Physiol., Lond. 192, 63.

Baile, C. A. \& Forbes, J. M. (1974). Physiol. Rev. 54, I60.

Balch, C. C. \& Campling, R. C. (1962). Nutr. Abstr. Rev. 32, 669.

Bessou, P. \& Perl, E. R. (I966). J. Physiol., Lond. I82, 404.

Blaxter, K. L., Wainman, F. W. \& Wilson, R. S. (196I). Anim. Prod. 3, 5 I.

Blaxter, K. L. \& Wilson, R. S. (I962). Anim. Prod. 4, 35 I.

Carr, S. B. \& Jacobson, D. R. (I967). J. Dairy Sci. 50, I8I4.

Conrad, H. R., Pratt, A. D. \& Hibbs, J. W. (1964). J. Dairy Sci. 47, 54.

Crampton, E. W. (1957). J. Anim. Sci. 16, 546.

Crampton, E. W., Donefer, E. \& Lloyd, L. E. (1960). J. Anim. Sci. 19, 538.

Crowcroft, P. J., Holman, M. E. \& Szurszewski, J. H. (I97I). J. Physiol., Lond. 219, 443.

Debons, A. F. \& Krimsky, I. (1972). Postgrad. med. 51, 74.

Gernandt, B. \& Zotterman, Y. (I 946). Acta physiol. scand. 12, 56.

Grovum, W. L. \& Williams, V. J. (1977). Br. J. Nutr. 38, 425.

Harding, R. \& Leek, B. F. (1972). J. Physiol., Lond. 222, I39P.

Hertz, A. F. (1911). In The Sensibility of the Alimentary Canal, pp. I6-35. London: Oxford University Press.

Hill, R. G., Ison, E. C., Jones, W. W. \& Archdeacon, J. W. (1952). Am. J. Physiol. 170, 201.

Hoelzel, F. (1947). Am. J. dig. Dis. 14, 401.

Iggo, A. (1955). J. Physiol., Lond. 128, 593.

Iggo, A. (1957a). Q. Jl exp. Physiol. 42, I 30.

Iggo, A. (19576). Q. Jl exp. Physiol. 42, 398.

Janowitz, H. D. \& Grossman, M. I. (I949a). Am. J. Physiol. 158, 184.

Janowitz, H. D. \& Grossman, M. I. (1949b). Am. J. Physiol. 159, 143.

Johns, A. T., Ulyatt, M. J. \& Glenday, A. C. (1963). J. agric. Sci., Camb. 6r, 201.

Lawrence, T. L. J. (1972). Vet. Rec. 91, 84.

Lehmann, F. (I941). Z. Tierphysiol. Tierernahr. Futtermittelk. 5, 155.

Machle, W., Heyroth, F. F., \& Witherup, S. (1944). J. biol. Chem. r53, 55 I.

Moinuddin, J. F. \& Lee, H. W. (1959). Am. J. Physiol. r97, 903.

Montgomery, M. J. \& Baumgardt, B. R. (1965). J. Dairy Sci. 48, 569.

Mraz, F. R., Boucher, R. V. \& McCartney, M. G. (1957). Poult. Sci. 36, 1217.

Oomura, Y., Ooyama, H., Yamamoto, T. \& Naka, F. (1967). Physiol. Behav. 2, 97.

Paintal, A. S. (1954). J. Physiol., Lond. 126, 255.

Paintal, A. S. (1957). J. Physiol., Lond. 139, 353.

Peterson, D. W., Grau, C. R. \& Peek, N. F. (1954). J. Nutr. 52, 24 I.

Pettyjohn, J. D., Everett, J. P. \& Mochrie, R. D. (1963). J. Dairy Sci. 46, 7 Io.

Rae, A. L., Brougham, R. W., Glenday, A. C. \& Butler, G. W. (1963). J. agric. Sci., Camb. 6r, 187.

Rand, N. T., Scott, H. M. \& Kummerow, F. A. (1956). Poult. Sci. 35, I 66.

Reese, E. T., Siu, R. G. H. \& Levinson, H. S. (1950). J. Bact. 59, 485.

Sharma, K. N., Anand, B. K., Dua, S. \& Singh, B. (196I). Am. J. Physiol. 201, 593.

Sibbald, I. R., Slinger, S. J. \& Ashton, G. C. (1960). J. Nutr. 72, 44 I. 
Snedecor, G. W., \& Cochran, W. G. (1967). In Statistical Methods, pp. 273-5. Ames, Iowa: The Iowa State University Press.

Stominger, J. L., Brobeck, J. R. \& Cort, R. L. (1953). Yale J. Biol. Med. 26, 55.

Tainter, M. L. \& Buchanan, O. H. (1954). Ann N.Y. Acad. Sci. 58, 438.

Ulyatt, M. J., Blaxter, K. L. \& McDonald, I. (1967). Anim, Prod. 9, 463.

Welch, J. G. (1967). J. Anim. Sci. 26, 849.

Yudkin, J. (I959). Lancet ii, I I 35. 